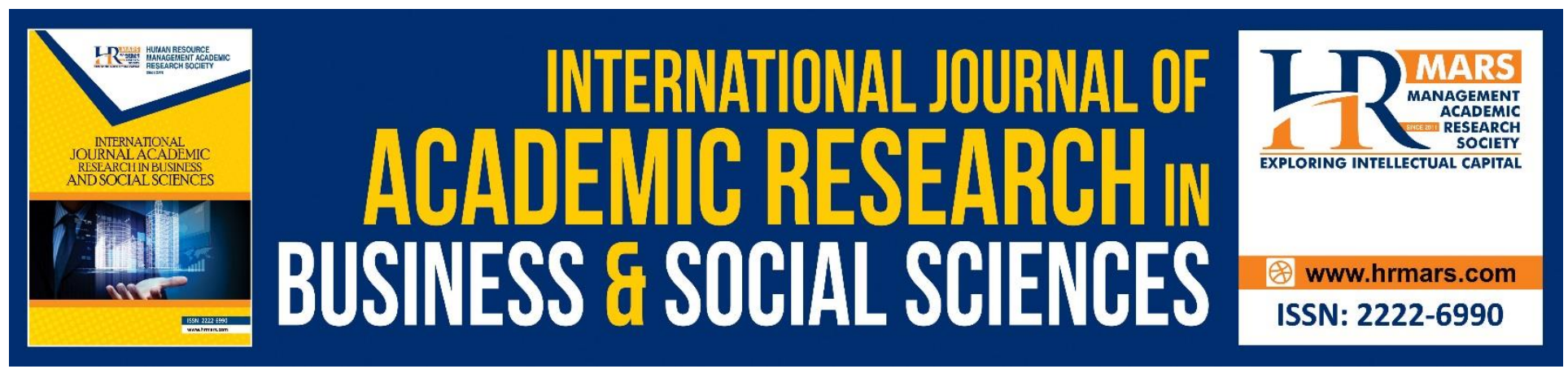

\title{
Use of Natural Pozzolanic Material as Partial Replacement Ordinary Portland Cement (OPC) in Concrete
}

Rahim Ishak, Sinatu Sadiah Shapie, Jau Choy Lai

To Link this Article: http://dx.doi.org/10.6007/IJARBSS/v10-i9/7987

DOI:10.6007/IJARBSS/v10-i9/7987

Received: 08 July 2020, Revised: 25 July 2020, Accepted: 19 August 2020

Published Online: 29 September 2020

In-Text Citation: (Ishak, Shapie, \& Lai, 2020)

To Cite this Article: Ishak, R., Shapie, S. S., \& Lai, J. C. (2020).Use of Natural Pozzolanic Material as Partial Replacement Ordinary Portland Cement(OPC) in Concrete. International Journal of Academic Research in Business and Social Sciences. 10(9), 1077-1087

Copyright: (C) 2020 The Author(s)

Published by Human Resource Management Academic Research Society (www.hrmars.com)

This article is published under the Creative Commons Attribution (CC BY 4.0) license. Anyone may reproduce, distribute, translate and create derivative works of this article (for both commercial and non-commercial purposes), subject to full attribution to the original publication and authors. The full terms of this license may be seen at: $\underline{\text { http://creativecommons.org/licences/by/4.0/legalcode }}$

Vol. 10, No. 9, 2020, Pg. 1077 - 1087

http://hrmars.com/index.php/pages/detail/IJARBSS

JOURNAL HOMEPAGE

Full Terms \& Conditions of access and use can be found at http://hrmars.com/index.php/pages/detail/publication-ethics 


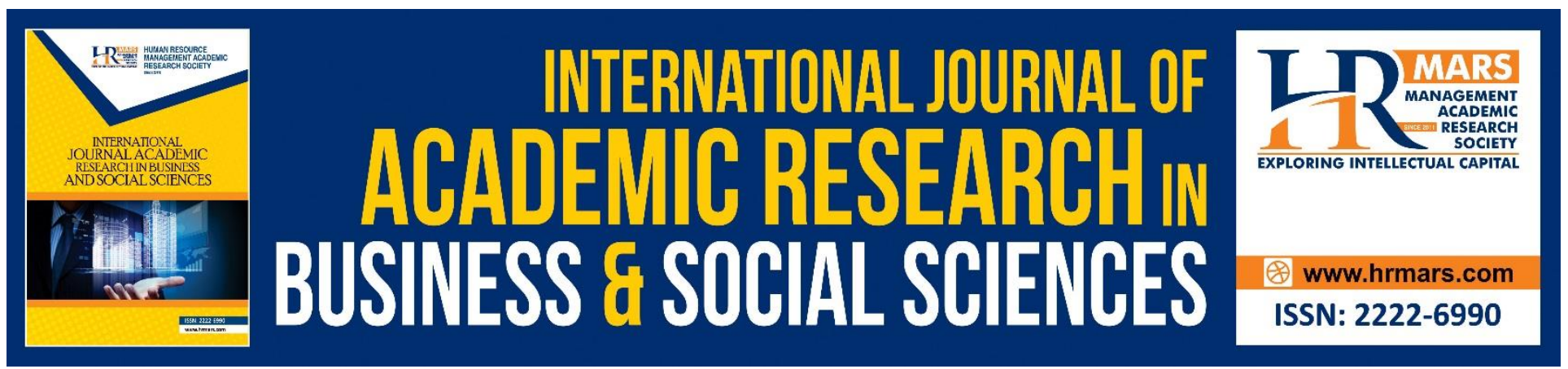

\title{
Use of Natural Pozzolanic Material as Partial Replacement Ordinary Portland Cement(OPC) in Concrete
}

\author{
Rahim Ishak, Sinatu Sadiah Shapie \\ Civil Engineering Department, Politeknik Melaka \\ Email: rahimishak@polimelaka.edu.my,_s_sadiah@polimelaka.edu.my \\ Jau Choy Lai \\ Universiti Teknologi Malaysia \\ Email: jclai@utm.my
}

\begin{abstract}
Fly ash is a powder material of burned coal from thermal power stations which produces cementitious and pozzolanic material. Commonly use of fly ash in concrete for building construction contributes conducive environmental and also reduces the effect of pollutant in site project. Therefore, this study was conducted to investigate the use of fly ash as partial replacement of cement in concrete as a mean of producing more environmental friendly concrete. The content of fly ash as partial replacement of ordinary portland cement(OPC) is investigated by weight accordingly in range $0 \%$ (without fly ash), $10 \%, 20 \%$ and $30 \%$ for grade 25 . The chemical composition of fly ash was determine using X-ray Fluorescence (XRF). The scanning electron microscope (SEM) was used to determine particle size, shape and texture of fly ash. The mix proportion of concrete was determine using mix design method according to British Standard. The workability of the fresh concrete mixture was evaluated using slump test while compressive strength of cubes concrete was evaluated at 7, 14, 28 and 56 days. A total of 48 cubes concrete with size $100 \mathrm{~mm} \times 100 \mathrm{~mm} \times 100 \mathrm{~mm}$ were made. The optimum compressive strength at all ages of testing was obtained at $10 \%$ replacement. Workability decreased with an increased in replacement percentage of fly ash. The results therefore show that fly ash as pozzolanic materials can be used to partially replace ordinary portland cement in production of concrete.
\end{abstract}

Keywords: Pozzolanic Material, Fly Ash, Compressive Strength and Workability

\section{Introduction}

The rapid development of the construction industry in Malaysia requires the use of very high materials, especially concrete building materials. Continuous and uncontrolled use of materials eventually leads to running out of raw material stocks for example non-renewable materials such as 
aggregates and cement materials. Beside that, Production of Portland cement is energy intensive and accounts for $2.4 \%$ of the total global CO2 emission from industries (Falayi, Okonta, \& Ntuli, 2017) One of the most significant activities stressed by the engineers and scientists related to concrete industry aims at a high percentage of replacement of clinker in cement with secondary raw materials, with the possibility of improvement of cement characteristics and durability of concrete.(Kanojia, Dholia, \& Rao, n.d.). Replacement materials are usually available in large quantities and can be used to replace Portland cement in green concrete, which include Fly Ash (Fly Ash is a solid waste product dumped in large quantities by thermal Power Plants in Malaysia).

Fly ash is a fine powder which is an industrial waste that is produced from of burning pulverized coal in electric generation power plants. Fly ash is a pozzolanic material that containing aluminous and siliceous material that forms cement in the presence of water. Fly ash forms a compound similar to cement when existing of lime and water. Fly ash can be classified as class $F$ and class C according to ASTM C618 and grade I and grade II according to I.S. 3812 (Gourav \& Venkatarama Reddy, 2014). Gourav et al, (2014) said the classification of Fly Ash were depending on lime content and focused on lime reactivity. These value indicates the reactivity of pozzolanic materials measures by testing a standard cube specimen for compressive strength following the guidelines of I.S. 3812 code.

Choure et al, (2017) reported that using fly ash in concrete mix as replacement of cement, increase its compressive strength. Abu Bakar et al, (2012) stated the compressive strength of bottom ash and cement blended with fly ash showed that the result was lower compared to that of the control concrete. Fly ash can be classified in class $\mathrm{C}$ and $\mathrm{F}$. The class $\mathrm{F}$ has a low lime ( $\mathrm{CaO}$ ) content and its content of $\mathrm{SiO}_{2}+\mathrm{Fe}_{2} \mathrm{O}_{3}+\mathrm{Al}_{2} \mathrm{O}_{3}$ is greater than 70 (ASTM C 618). Yazici et al, (2012) mentioned concretes in containing fly ash that is used at the same rate instead of cement shows compressive strength of the produced concretes increase as fineness of fly ash increases.

Englehard et al. (1995) mentioned pozzolana is a siliceous and aluminous material that in itself possesses little to no cementitious value. However, in finely divided form and in the presence of moisture, it is able to chemically react with calcium hydroxide (lime) at ordinary temperatures to form compound having cementitious properties. Malhotra, et al, (2000) stated fly ash as one of the potential material in reducing the use of cement in construction as it possesses similar binding ability as of cement while containing little to no hazardous chemical substances, making it a more viable and environmentally friendly alternative. However, the study on chemical composition, compressive strength and workability of concrete containing fly ash is still considerably limited in Malaysia. Therefore, this study aims to investigate fly ash to partially replace cement. The fly ash used in this work was provided by Jimah Energy Ventures Power Plant. Therefore, the proposed admixture will be a perfect component of green concrete and its utilization will be a valuable resource for recycling. Mechanical properties of concrete made with the partial replacement of cement, with Fly Ash concrete were studied in this work.

\section{Materials and Methods \\ Materials}

The cement used was ordinary portland cement in compliance to BS12:1996, while the pozzolanic material used was fly ash with conformance with ASTM C618. The fly ash obtained from Jimah Energy Ventures Power Plant, Negeri Sembilan. Coarse aggregates of nominal size $20 \mathrm{~mm}$ was used in producing concrete and complied to BS 882:1996. River sand (fine aggregate) was used in this study 
INTERNATIONAL JOURNAL OF ACADEMIC RESEARCH IN BUSINESS AND SOCIAL SCIENCES Vol. 10, No. 9, 2020, E-ISSN: 2222-6990 @ 2020 HRMARS

and complied to BS 882:1996. Clean water was also added in the mixing of concrete. Grade 25 concrete was produced using a water binder ratio of 0.55 . Four different mixes were used for this study according British Standard (Department of Environment) mix design method of concrete. An attempt is made by partial replacement of Cement. These four mixes includes a control mix using OPC without of fly ash and other three mixes with fly ash replacement $10 \%, 20 \%$ and $30 \%$ by mass of OPC as in the control mix. When compound admixture with Fly Ash is mixed with concrete, the performance of concrete can be improved further due to the synergistic effect and activation of each other.

\section{Experimental Tests}

The chemical composition of fly ash was conducted using X-ray Fluorescence (XRF) at Universiti Teknologi Malaysia. The particle size, shape and texture of fly ash was determine using scanning electron microscope (SEM). The mix design of concrete was done according to British method of concrete mix design for grade 25 . The slump test was used to evaluate the workability of the mix of concrete. Workability depends on water content, aggregate (shape and size distribution) and cementitious content. The specified size of cube concrete moulds $100 \mathrm{~mm} \times 100 \mathrm{~mm} \times 100 \mathrm{~mm}$ was used. A total of 48 cubes were made. The specimens were made in accordance to BS 1881-116:1983. Demoulding was done after 24 hours and the specimens were placed in a curing tank. The compressive strengths were determined by compressing the concrete cubes at 7, 14, 28 and 56 days using a 2,000kN Matest compression testing machine at Concrete Laboratory, Politeknik Melaka in accordance to BS 1881-116:1983. The specimens were taken out of the curing tank and placed in open air about 2 hours before compress.

\section{Results and Analysis}

The chemical compositions of cement and fly ash that used in this study shows in Table 1 while Figure 1 shows the particle size, shape and texture of fly ash. According to ASTM 618-05, class F of fly ash stated as silicon dioxide $\left(\mathrm{SiO}_{2}\right)+$ aluminium oxide $\left(\mathrm{Al}_{2} \mathrm{O}_{3}\right)+$ iron oxide $\left(\mathrm{Fe}_{2} \mathrm{O}_{3}\right)$ is not less than $70 \%$ and calcium oxide $(\mathrm{CaO})$ is less than $10 \%$. Result from table 1 shows $\left(\mathrm{SiO}_{2}\right)+\left(\mathrm{Al}_{2} \mathrm{O}_{3}\right)+\left(\mathrm{Fe}_{2} \mathrm{O}_{3}\right)$ is $88 \%$ and can be classified as class $\mathrm{F}$.

Table 1: Chemical Composition of OPC and Fly Ash

\begin{tabular}{ccc}
\hline Component & Ordinary Portland Cement (\%) & $\begin{array}{c}\text { Pozzolanic Material } \\
\text { (Fly Ash Type F)(\%) }\end{array}$ \\
\hline $\mathrm{SiO}_{2}$ & $17-25$ & 60 \\
\hline $\mathrm{CaO}$ & $60-67$ & 3.36 \\
\hline $\mathrm{Al}_{2} \mathrm{O}_{3}$ & $3.0-8.0$ & 21 \\
\hline $\mathrm{Fe}_{2} \mathrm{O}_{3}$ & $0.5-6.0$ & 7 \\
\hline $\mathrm{MgO}$ & $0.1-4.0$ & 1.24 \\
\hline $\mathrm{SO}_{3}$ & $1.3-3.0$ & 0.664 \\
\hline $\mathrm{Na}_{2} \mathrm{O}$ & $0.4-1.3$ & 1.5 \\
\hline $\mathrm{K}_{2} \mathrm{O}$ & $0.4-1.3$ & 1.88 \\
\hline
\end{tabular}

Microstructure with Scanning Electron Micrograph (SEM) in Figure 1 shows the SEM of the original fly ash from JIMAH Venture Power plant consist of mostly glassy and spherical particles. Sizes of particles fly ash are $1.0 \mu \mathrm{m}-7.6 \mu \mathrm{m}$ and the fly ash reacts with free lime in the existing of water and 
INTERNATIONAL JOURNAL OF ACADEMIC RESEARCH IN BUSINESS AND SOCIAL SCIENCES Vol. 10, No. 9, 2020, E-ISSN: 2222-6990 @ 2020 HRMARS

converted into calcium silicate hydrate (C-S-H) which is the strongest and durable portion of the concrete. According to Glassy and spherical particles may help to reduce internal friction between aggregates thereby concrete containing fly ash increase consistency and allow mobility for longer pumping distances.

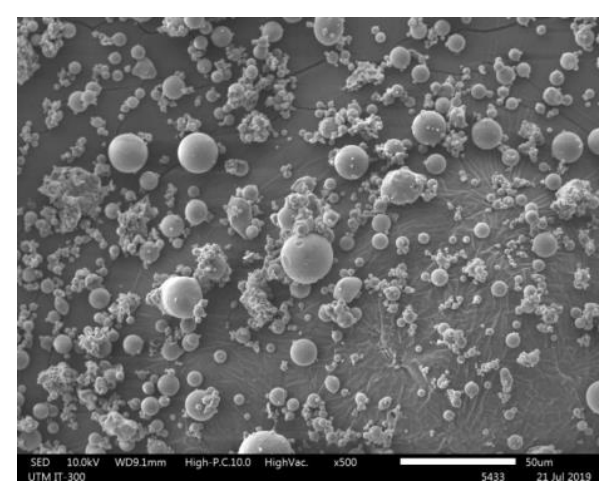

Figure 1: SEM of Fly Ash

The British method of concrete mix design was published by the British Department of the Environment (DOE) and commonly known as "DOE Method". The details of mix proportions are shown in Table 2. DOE mix design engaged several following stages.

i. Determination of target strength, $\mathrm{f}_{\mathrm{ck}}$

specified characteristic strength $=25 \mathrm{~N} / \mathrm{mm}^{2}$

standard deviation $=1.64$

risk factor $=8 \mathrm{~N} / \mathrm{mm}^{2}$

Target mean strength $=$ specified characteristic strength $+($ standard deviation $\mathrm{x}$ risk

factor)

$$
\begin{array}{r}
=25+(1.64 \times 8) \\
=38.12 \mathrm{~N} / \mathrm{mm}^{2}
\end{array}
$$

$\mathrm{f}_{\mathrm{ck}}=$ Characteristic Compression Strength at 28 days

ii. Determination of water cement ratio

Design of water cement ratio $=0.55$.

iii. Calculation Of Water Content

$W_{f}=$ Free water content appropriate to type of fine aggregate

$W_{c}=$ Free water content appropriate to type of coarse aggregate

Type of slump test $30-60 \mathrm{~mm}$

Water content $=\frac{2}{3} W_{f}+\frac{1}{3} W_{c}$

$$
=\frac{2}{3}(180)+\frac{1}{3}(210)
$$


INTERNATIONAL JOURNAL OF ACADEMIC RESEARCH IN BUSINESS AND SOCIAL SCIENCES Vol. 10, No. 9, 2020, E-ISSN: 2222-6990 (C) 2020 HRMARS

$$
=190 \mathrm{~kg} / \mathrm{m}^{3}
$$

Maximum water content required for $20 \mathrm{~mm}$ nominal maximum size of aggregate $=190 \mathrm{~kg} / \mathrm{m}^{3}$

iv. Determination of cement content

Mixing water content is $190 \mathrm{~kg} / \mathrm{m}^{3}$ of concrete.

$$
\begin{aligned}
& \text { Cement content }=\frac{\text { Water content }}{\text { Water cement ratio }} \\
& =\frac{190}{0.55} \\
& =345.45 \mathrm{~kg} / \mathrm{m}^{3}
\end{aligned}
$$

Maximum cement content required $=345.45 \mathrm{~kg} / \mathrm{m}^{3}$

v. Determination of total aggregate

Water content: $190 \mathrm{~kg} / \mathrm{m}^{3}$

Uncrushed aggregate: $20 \mathrm{~mm}$

Specific gravity: 2.6

The wet density $=2375 \mathrm{~kg} / \mathrm{m}^{3}$

Weight of Total Aggregate $=$ The wet density - (Weight of Cement + Weight of Free Water)

Weight of Total Aggregate $=2375-(345.45+190)$

$$
=1839.55 \mathrm{~kg} / \mathrm{m}^{3}
$$

Percentage of fine aggregate $=49 \%$

Weight of fine aggregate $=1839.55 \times 0.49$

$$
=901.38 \mathrm{~kg} / \mathrm{m}^{3}
$$

Weight of course aggregate $=183.55-901.38$

$$
=938.17 \mathrm{~kg} / \mathrm{m}^{3}
$$

Table 2: Details of mix proportions of concrete grade 25

\begin{tabular}{ccccccc}
\hline $\begin{array}{c}\text { Percentage } \\
\text { replacement(\%) }\end{array}$ & $\begin{array}{c}\text { Weight of Materials } \\
\left(\mathbf{k g} / \mathbf{m}^{3}\right)\end{array}$ & $\begin{array}{c}\text { Fly Ash } \\
\left(\mathbf{k g} / \mathbf{m}^{3}\right)\end{array}$ & $\begin{array}{c}\text { River } \\
\text { Sand } \\
\left(\mathbf{k g} / \mathbf{m}^{3}\right)\end{array}$ & $\begin{array}{c}\text { Coarse } \\
\text { Aggregate } \\
\left(\mathbf{k g} / \mathbf{m}^{3}\right)\end{array}$ & $\begin{array}{c}\text { Water } \\
(\mathbf{L})\end{array}$ & $\begin{array}{c}\text { Target Mean Strength } \\
\left(\mathbf{N} / \mathbf{m m}^{2}\right)\end{array}$ \\
\hline 0 & 345.45 & 0 & 901.38 & 938.17 & 190 & 38.12 \\
\hline 10 & 310.91 & 34.5 & 901.38 & 938.17 & 190 & 38.12 \\
\hline 20 & 276.50 & 69.0 & 901.38 & 938.17 & 190 & 38.12 \\
\hline 30 & 242.0 & 104 & 901.38 & 938.17 & 190 & 38.12 \\
\hline
\end{tabular}


INTERNATIONAL JOURNAL OF ACADEMIC RESEARCH IN BUSINESS AND SOCIAL SCIENCES Vol. 10, No. 9, 2020, E-ISSN: 2222-6990 @ 2020 HRMARS

The details of coarse aggregate sieve analysis shows in Table 3 while Figure 2 shows the semi log graph of coarse aggregate sieve analysis. The coarse aggregate used in experiments were purchased from local market in Melaka. From the results, sample of coarse aggregate in all sizes within the limitation and complied to BS 882:1996

Table 3: Sieve Analysis of Coarse Aggregate

\begin{tabular}{cccccc}
\hline $\begin{array}{c}\text { Aggregate } \\
\text { size }(\mathbf{m m})\end{array}$ & $\begin{array}{c}\text { Weight } \\
\text { Retained(g) }\end{array}$ & $\begin{array}{c}\text { Individual } \\
\text { Percent } \\
\text { Retained (\%) }\end{array}$ & $\begin{array}{c}\text { Cumulative } \\
\text { Weight } \\
\text { Retained(g) }\end{array}$ & $\begin{array}{c}\text { Cumulative } \\
\text { Percent } \\
\text { Retained (\%) }\end{array}$ & $\begin{array}{c}\text { Calculated } \\
\text { Percent } \\
\text { Passing (\%) }\end{array}$ \\
\hline 28 & 0 & 0 & 0 & 0 & 100 \\
\hline 20 & 2158 & 78.79 & 2158.00 & 78.79 & 21.21 \\
\hline 14 & 508 & 18.55 & 2666.00 & 97.33 & 2.67 \\
\hline 10 & 69 & 2.52 & 2735.00 & 99.85 & 0.15 \\
\hline 5 & 4 & 0.15 & 2739.00 & 100.00 & 0.00 \\
\hline 2.36 & 0 & 0 & 2739.00 & 100.00 & 0.00 \\
\hline Pan & 0 & 0 & 2739.00 & 100.00 & 0.00 \\
\hline Total & 2739 & & & & \\
\hline
\end{tabular}

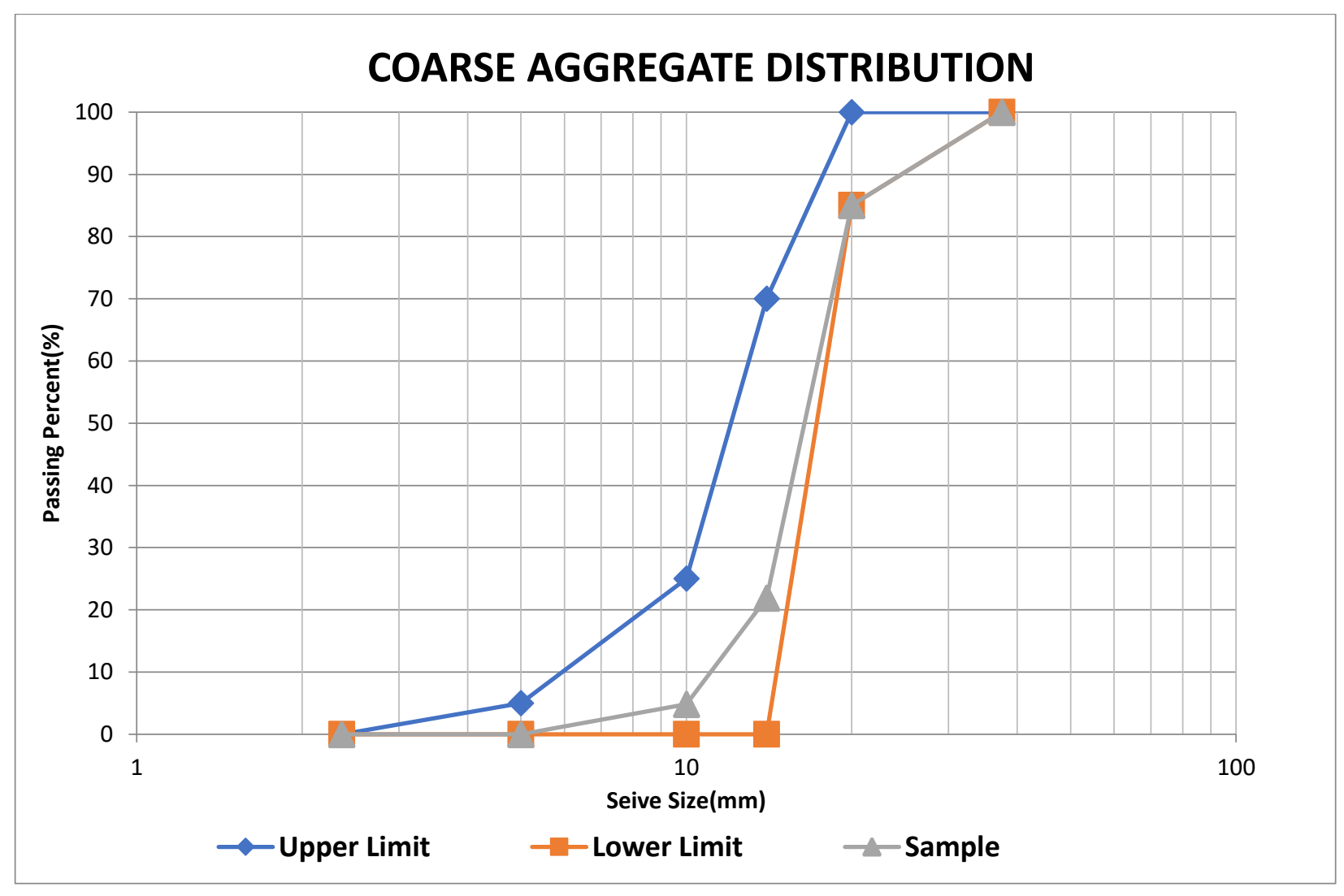

Figure 2: Sieve Analysis of Coarse Aggregate (BS 882:1996) 
INTERNATIONAL JOURNAL OF ACADEMIC RESEARCH IN BUSINESS AND SOCIAL SCIENCES Vol. 10, No. 9, 2020, E-ISSN: 2222-6990 @ 2020 HRMARS

Table 4 shows the details of fine aggregate sieve analysis while Figure 3 shows the semi log graph of river sand analysis. The river sand used in experiments were purchased from local market in Melaka. From the results, sample of river sand in all sizes is within the limitation and complied to BS 882:1996.

Table 4: Sieve Analysis of River Sand

\begin{tabular}{cccccc}
\hline $\begin{array}{c}\text { Aggregate } \\
\text { size(mm) }\end{array}$ & $\begin{array}{c}\text { Weight } \\
\text { Retained(g) }\end{array}$ & $\begin{array}{c}\text { Individual } \\
\text { Percent } \\
\text { Retained (\%) }\end{array}$ & $\begin{array}{c}\text { Cumulative } \\
\text { Weight } \\
\text { Retained(g) }\end{array}$ & $\begin{array}{c}\text { Cumulative } \\
\text { Percent } \\
\text { Retained (\%) }\end{array}$ & $\begin{array}{c}\text { Calculated } \\
\text { Percent } \\
\text { Passing (\%) }\end{array}$ \\
\hline 10 & 0 & 0 & 0 & 0 & 100 \\
\hline 5 & 81 & 7.83 & 81.00 & 7.83 & 92.17 \\
\hline 2.36 & 272 & 26.31 & 353.00 & 34.13 & 65.86 \\
\hline 1.18 & 324 & 31.33 & 677.00 & 65.47 & 34.53 \\
\hline 0.6 & 192 & 18.57 & 869.00 & 84.04 & 15.96 \\
\hline 0.3 & 94 & 9.09 & 963.00 & 93.13 & 6.87 \\
\hline 0.15 & 60 & 5.80 & 1023.00 & 98.94 & 1.07 \\
\hline Pan & 11 & 1.06 & 1034.00 & 100 & 0 \\
\hline Total & 1034 & & & & \\
\hline
\end{tabular}

\section{RIVER SAND DISTRIBUTION}

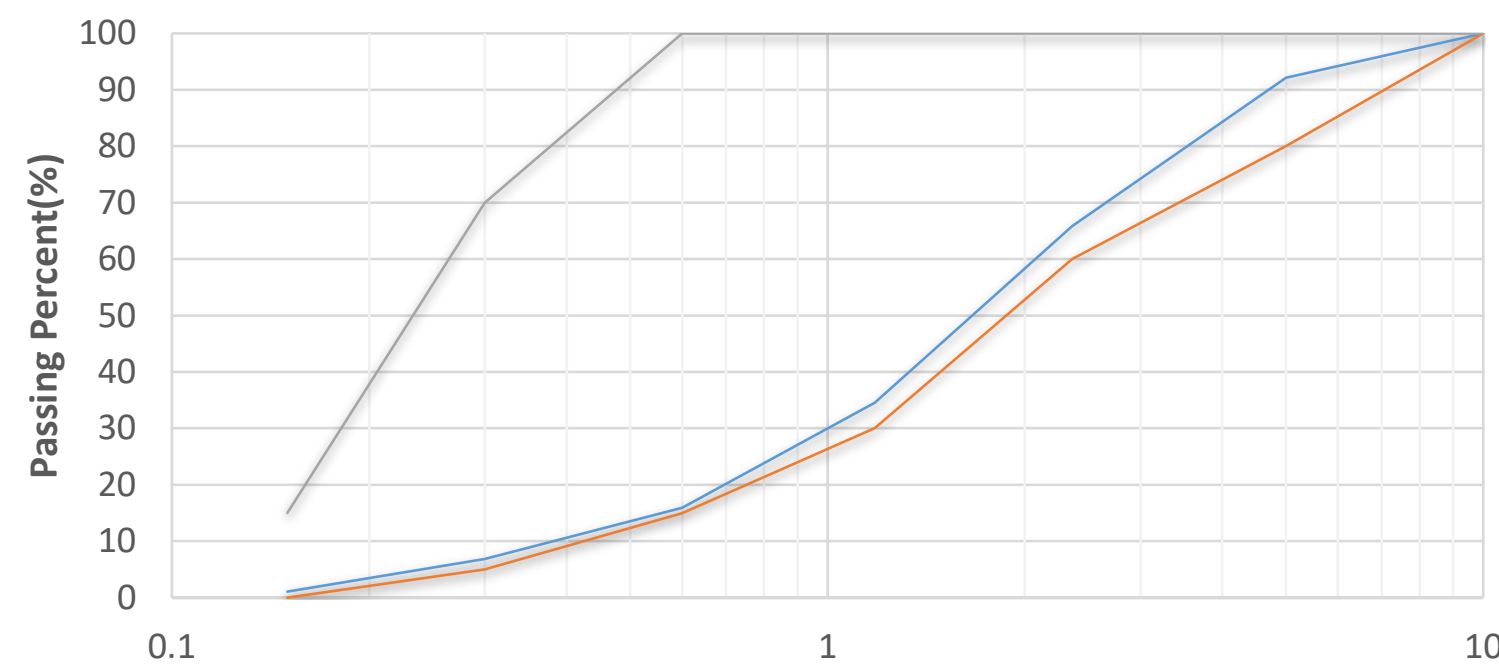

Seive Size $(\mathrm{mm})$

$\triangle$-Sample $\quad-$ - Lower Limit $\rightarrow$ Upper Limit

Figure 3: Sieve Analysis of River Sand (BS 882:1996)

\section{Slump Test}

The results of workability tests shows in Table 5 while graph of workability of fresh concrete containing a partial of fly ash shows in Figure 4. Generally, it is observed that the percentage of fly 
INTERNATIONAL JOURNAL OF ACADEMIC RESEARCH IN BUSINESS AND SOCIAL SCIENCES Vol. 10, No. 9, 2020, E-ISSN: 2222-6990 @ 2020 HRMARS

ash in mix of concrete increased, the workability of concrete decreased. Therefore, increasing replacement of cement with fly ash will be increased water demand in fresh concrete mix.

Table 5: Workability Test

\begin{tabular}{ccccc}
\hline Workability & \multicolumn{4}{c}{ Cement Replacement (\%) } \\
\cline { 2 - 5 } & $\mathbf{0}$ & $\mathbf{1 0}$ & $\mathbf{2 0}$ & $\mathbf{3 0}$ \\
\hline Slump $(\mathrm{mm})$ & 63 & 61 & 60 & 57 \\
\hline
\end{tabular}

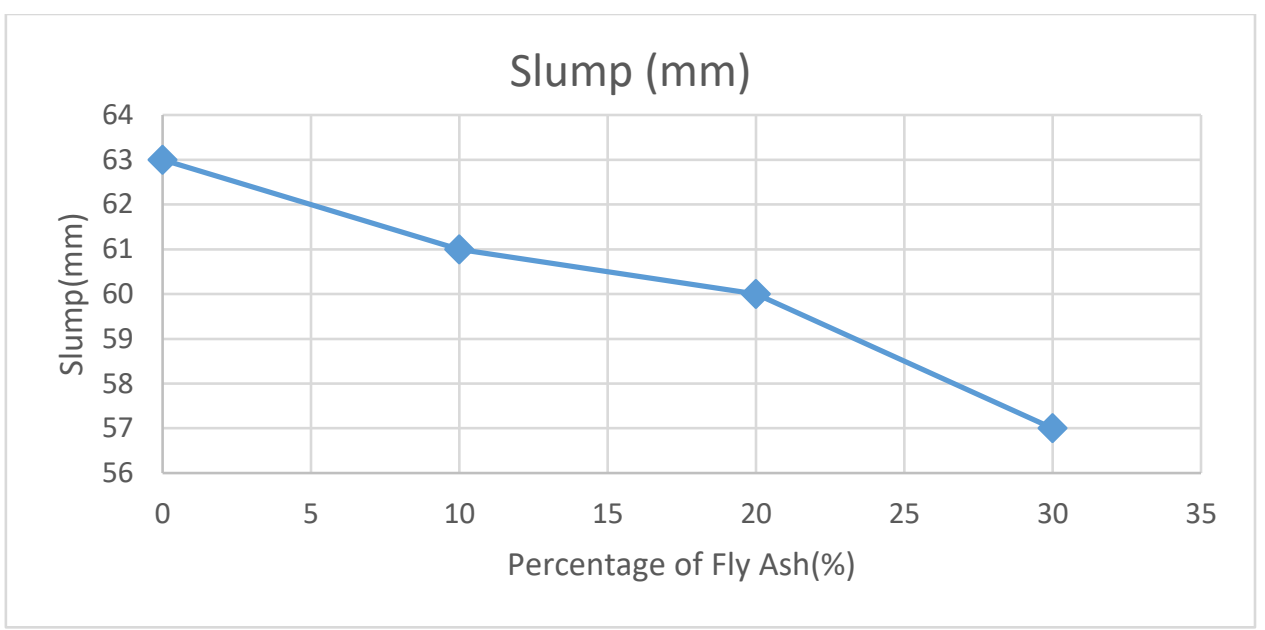

Figure 4: Graph of Slump Test

\section{Compressive Strength}

The relationship between compressive strength and difference percentage of fly ash at age 7 days, 14 days, 28 days and 56 days shows in Figure 5 while Table 6 shows the results of compressive strength of concrete with partial replacement of fly ash. The compressive test was conducted to determine the compressive strength of concrete at the age of 7, 14, 28 and 56 days. The compressive strength of concrete also increases with age. The maximum compressive strength $\left(43.57 \mathrm{~N} / \mathrm{mm}^{2}\right)$ was seen at $10 \%$ replacement of OPC with fly ash at 56 days and exceed target mean strength $\left(38.12 \mathrm{~N} / \mathrm{mm}^{2}\right)$ but lower than control concrete $\left(40.61 \mathrm{~N} / \mathrm{mm}^{2}\right)$. The increased in compressive strength at 56 days may be due to slow hydration process when increased of fly ash in concrete which is slow reactive pozzolans causes delay the hydration process at 28 days.

Table 6: Compressive Strength ( $\left.\mathrm{N} / \mathrm{mm}^{2}\right)$

\begin{tabular}{ccccc}
\hline $\begin{array}{c}\text { Concrete Age } \\
\text { (days) }\end{array}$ & \multicolumn{5}{c}{ Fly ash replacement percentage (\%) } \\
\cline { 2 - 5 } & $\mathbf{0}$ & $\mathbf{1 0}$ & $\mathbf{2 0}$ & $\mathbf{3 0}$ \\
\hline 7 & 24.15 & 24.50 & 27.27 & 23.20 \\
\hline 14 & 35.33 & 35.61 & 30.93 & 25.03 \\
\hline 28 & 39.89 & 37.74 & 34.26 & 33.54 \\
\hline 56 & 40.61 & 43.57 & 37.80 & 37.61 \\
\hline
\end{tabular}


INTERNATIONAL JOURNAL OF ACADEMIC RESEARCH IN BUSINESS AND SOCIAL SCIENCES Vol. 10, No. 9, 2020, E-ISSN: 2222-6990 @ 2020 HRMARS

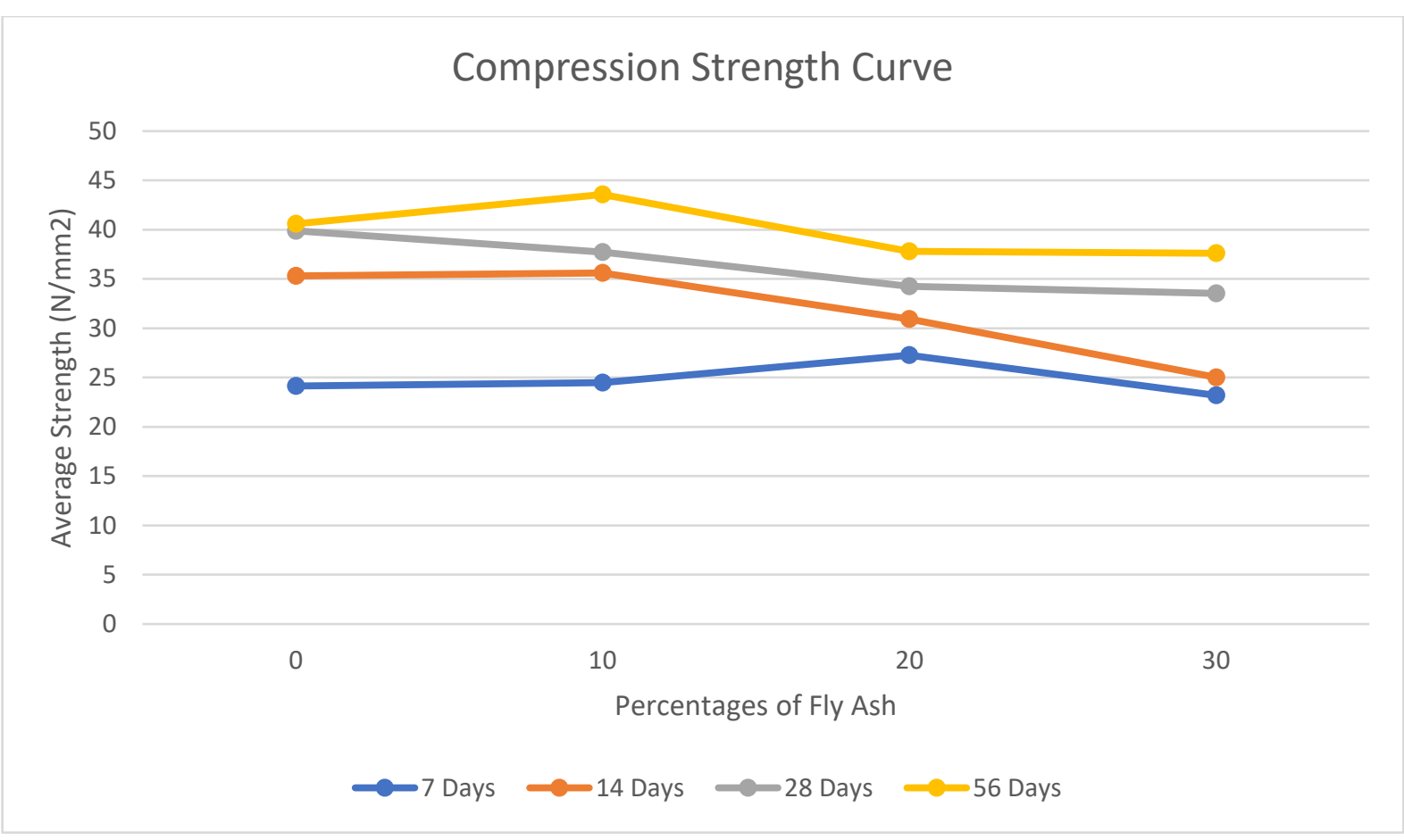

Figure 5: Relationship between compressive strength and difference percentage of fly ash at age 7 days, 14 days, 28 days and 56 days

\section{Conclusion}

In this study, fly ash was used as partial replacement of OPC in difference percentage of 0\% (control), $10 \%, 20 \%$ and $30 \%$. From the XRF test shows calcium oxide ( $\mathrm{CaO}$ ) is less than $10 \%$ can be concluded that fly ash as class $F$ and has a little cementitious properties. Thus, from the SEM, the shape of fly ash is spherical. The spherical shape of fly ash can reduce internal friction thereby increasing the concrete consistency and allow mobility for longer pumping distances. Based on this study, the replacement of cement with fly ash significantly decrease the compressive strength of concrete. From Table 6 , it is deduced that fly ash replacement of $10 \%$ of the weight of cement achieved the optimum value of compressive strength and considered the best ratio of cement replacement in a concrete mix at 56 days. From the slump test, the increase in fly ash content in concrete decreases the slump height, thus indicating that there is a decrease in the workability of concrete. Therefore, from this study, the partial replacement of cement by fly ash definitely more economical alternative and potential utilize in the field of construction industry with reducing environmental impact to surrounding. However, further study needs to be done on wide range of characteristics of concrete.

\section{References}

ASTM C C168: Standard specification for coal fly ash and raw or calcined natural for use in concrete. British Standard Institution, BS 1881: Part 102:1983. Method for determination of slump, BSi. London British Standard Institution, BS 1881: Part 116:1983. Method for determination of compressive strength of concrete, BSi. London

British Standard Institution.,BS 882:1992. Specification of aggregates from natural sources for concrete, BSi. London 
INTERNATIONAL JOURNAL OF ACADEMIC RESEARCH IN BUSINESS AND SOCIAL SCIENCES

Vol. 10, No. 9, 2020, E-ISSN: 2222-6990 @ 2020 HRMARS

British Standard Institution.,BS 410:1986. Specification for test sieves, BSi. London

Abu Bakar, A. U., \& Baharudin, K.S. (2012). Properties of Concrete Using Tanjung Bin Power Plant Coal Bottom Ash and Fly ash. International Journal of Sustainable Construction Engineering \& Technology, 3(2), 56-69.

Choure, A., \& Chandak, R. (2017). Experimental Study on Concrete Containing Fly Ash. International Research Journal of Engineering and Technology, 4(2), 202-205.

Englehardt, J. D., \& Peng, C. (1995). Pozzolanic Filtration/Solidification of Radionuclides in Nuclear Reactor Cooling Water. Waste Management Journal, 585-592.

Falayi, T., Okonta, F. N., \& Ntuli, F. (2017). Desilication of fly ash and development of lightweight construction blocks from alkaline activated desilicated fly ash. International Journal of Environment and Waste Management, 20(3), 233-253. https://doi.org/10.1504/IJEWM.2017.087152

Gourav, K., \& Reddy, V. B. V. (2014). Characteristics of compacted fly ash bricks and fly ash brick masonry. Journal of Structural Engineering (India), 41(2), 144-157.

Kanojia, A., Dholia, N., \& Rao, V. V. N. P. (n.d.). Optimization of cement \& Fine Aggregate wit $h$ " High Lime Fly Ash \& LCMS Fil ing in Concrete."

Malhotra, V. M., \& Bilodeau, A. (2000). High-Volume Fly Ash System. Concrete Solution for Sustainable Development.

Yazici, S., Sahan, H. (2012).Effect of Fly Ash Fineness on The Mechanical Properties of Concrete. Indian Acadeny Sciences Journal, 337(3), 389-403. 